\title{
Antioxidants Enhancement to the Immune Response of NIH Mice to Vero Cell Grown Rabies Virus Vaccine
}

\author{
Aly Fahmy Mohamed \\ Virology Department, Egyptian Organization for Biological Products and Vaccines (VACSERA \\ Holding Company), 51 Wezaret El-Zeraa St., Agouza, Giza, Egypt.
}

\begin{abstract}
Introduction: Rabies cell culture vaccine (Vero-Rab) showed to be more immunogenic and a higher and faster release of antibody titer could be detected than in case of using Fermi type vaccine, DEV and CECV. Result: The immune response of NIH mice immunized intramuscularly using both $\mathrm{vE}$ - Se adjuvated and non adjuvated Vero cell rabies virus vaccine (Vero-Rab) showed an elevation of antibody level of vaccinated mice groups more than the limits decided by WHO for a potent rabies virus vaccine. Also, two different immunization regimens were achieved, 5 single doses and 3 double doses of $\mathrm{vE}$-selenium adjuvated and non adjuvated Vero cell rabies virus vaccine. The antibodies developed against rabies virus vaccine could be detected 14 days post immunization using ELISA and IFA. The antibody level developed in sera of mice immunized, with either adjuvated and non adjuvanted Vero-Rab., using different immunization regimens, could protect mice against the challenge with 100 MICLD $_{50}$ of the challenge virus standard (CVS) after the end of the experiment, (6 months of the prim-vaccination).Conclusion: vE-Se as immune potentiator can enhance the immune response and single dose immunization regimen without $\mathrm{vE}-\mathrm{Se}$ as immune stimulant was preferred than double dose regimen.
\end{abstract}

Key words: Rabies vaccine, Immunization, Vitamin E - Selenium, ELISA, Immunofluorscent.

\section{Introduction}

Rabies is probably one of the oldest recorded infectious diseases of mankind The first rabies virus vaccine developed by Louis Pasteur surely had been used to eliminate or, at least, reduce rabies incidence. However, this goal has not been achieved yet because rabies virus is maintained in many animal reservoirs, including both domestic and wild animals (Plotkin,1996). Many attempts were made to produce cheap and safe rabies vaccine in different tissues. The use of human origin cell line substrate was achieved (Hayflick and Moorhead,1969; Meslin and Kaplan, 1996). Other cell culture vaccine candidates are inactivated, concentrated and purified vaccines; these vaccines could evoke much better immune response in animals and humans than that induced by duck embryo vaccine (DEV) and suckling or adult mice brain tissue vaccines. The antibody levels were higher and appeared earlier after immunization with cell culture vaccine than those induced post DEV (Wiktor 1969; Elkaramany.1987). Selenium is an essential trace element; is toxic at very high levels. Selenium is existing as an essential component of glutathione peroxidase; a seleno-enzyme that catalyze the reduction of lipid hydroperoxides to the corresponding alcohols or the conversion of $\mathrm{H} 2 \mathrm{O} 2$ to water. Consequently, selenium with glutathione peroxidase indirectly provides a line of defense against oxygen free radicals before they propagate a chain reaction, damaging cell membranes and components. Also, selenium and vitamin E (vE) act synergistically in the defense mechanisms against residual oxygen metabolites (ROM) and they protect the 
neutrophils and surrounding tissues (Boxer, 1986) Vitamin E, as an antioxidant, appears to be the first line of defense against per oxidation of fatty acids contained in cellular and sub cellular membranes. The role of trace elements in maintenance of immune system functioning is recognized by increased natural killers (NK) activity, cytotoxic T-cell activity, interleukin-2 (IL-2) receptors expression and cell proliferation. The interaction of trace elements and immunity is a complex process, because it is frequently associated with other nutritional elements. $\alpha$ Tochopherol and selenium as antioxidants work in concert although each element has different functions and pathway in the immune system. Their deficiency cause dysfunction of the cellular immunity without affecting B cell function and impaires the immune system ability to fight infections and reduces the infectious morbidity (Boxer, 1986 ; Kodama, 1996). Also, vitamin E was used successfully as an adjuvant post vaccination to enhance immune response without forming abscess in poultry, sheep, and mice as compared with the response obtained with the use of conventional adjuvants (Afzal et al., 1984). (Tengerdy and Lacetera, 1991). So, we aimed to monitor the immune reactivity of NIH mice to Vero cell rabies virus vaccine using both vE-selenium adjuvated and non adjuvated vaccines and the influence of the immunization regimen on the antibody level and its duration and neutralization capability of challenge virus standard (CVS).

\section{Materials and Methods}

Vero cell rabies virus vaccine $0.5 \mathrm{ml}$ /dose and vE-selenium as an adjuvant (300 $\mathrm{IU} / \mathrm{ml}-50 \mathrm{mg} / \mathrm{kg}$ ) were kindly supplied from the National Regularity Authority (NRA), Biological Product Research Unit. All experiments were performed using 21 days old out bred male NIH mice supplied by Egyptian Organization for Biological Products and Vaccines (VACSERA), animal house. An in-house anti rabies immune serum was prepared and evaluated according to (WHO, 1996). Two immunization regimens using $(0.1 \mathrm{ml}$ of $0.28 \mu \mathrm{l}$ of both vE-Selenium adjuvated and non-adjuvated vaccine were carried out using intramuscular rout of administration ; single dose regimen at day $0,3,7,14$ and 28 and double dose regimen administered at 0 and $14^{\text {th }}$ day. Anti-mouse conjugates, either peroxidase or FITC labeled (SigmaAldrich, USA) were used as $1 / 1000$ and $1 / 16$ final dilution to evaluate the antibody level using ELISA and IFA techniques respectively according to (WHO, 1996). Challenge Virus Standard (CVS- Indiana strain) is a standard virus produced in mice, was kindly supplied from rabies virus vaccine research unit VACSERA. 100 MICLD $_{50}$ of CVS was used in challenging of mice 6 months post immunization. Potency of reference anti-rabies immunoglobulin prepared in mice was determined according to (WHO, 1996; Fitzgerald and Rastog, 1985). Antibody levels in sera of mice immunized using the previously mentioned immunization regimens were evaluated in comparison to the in-house pre-determined reference rabies anti-mouse immunoglobulin using direct ELISA and IFA (El- Karamany, 1987, 1988 ; Hostnik and Grom, 1997 ; WHO, 1996 and Atanasiu,1973).

\section{Results}

Recorded data revealed that, antirabies immunoglobulin developed in sera of laboratory animals immunized with rabies virus vaccine and collected at 2 week interval using single and double dose regimens of immunization. Also, vEselenium was chosen as an immunostimulant to evaluate the immune reactivity to the adjuvated and non adjuvated rabies virus vaccine. Evaluation of developed antibodies to rabies virus vaccine using ELISA showed a higher antibody level in case of vaccination using 5-single doses and 3 double doses regimens of $\mathrm{vE}-$ selenium adjuvated vaccine than nonadjuvated vaccine. Also the antibody level developed post immunization using 5 single dose of adjuvated vaccines showed 


\section{Aly Fahmy Mohamed}

stationary phase of antibody level on the $4^{\text {th }}$ - $6^{\text {th }}$ week post immunization, while this phase was noticed on the $6^{\text {th }}-8^{\text {th }}$ week post immunization using double dose regimen. In the mean time, the antibody level detected post immunization of laboratory animals using 5 single dose regimen of nonadjuvated vaccine was higher than immune response developed post vaccination of laboratory animals with non-adjuvated double dose regimen (Table 1). Antibody level detected on the $6^{\text {th }}$ month post immunization could protect the immunized mice groups against challenge using CVS (100 MICLD M0 $_{50}$. Also, antibody level developed post immunization using the different immunization regimens could be detected using IFA, where the antibody developed against rabies virus vaccine could be detected 14 days post immunization. The highest antibody level was detected on the $12^{\text {th }}$ week post vaccination using 5 single dose of $\mathrm{vE}$ selenium adjuvated vaccine followed by the 5 single non-adjuvated vaccine and 3 double dose adjuvated vaccine regimens where the highest antibody levels were recorded on the $8^{\text {th }}-10^{\text {th }}$ week post vaccination. The least developed antibody level was recorded post vaccination of laboratory animals using double dose of non-adjuvated vaccine regimen and its highest record was on the $8^{\text {th }}$ week (Table 2).

Table 1. Comparative evaluation of antibody titer using ELISA in sera of experimentally immunized mice post receiving adjuvated and Non-adjuvated Vero cell rabies virus vaccine

\begin{tabular}{|c|c|c|c|c|}
\hline \multirow{2}{*}{$\begin{array}{c}\text { Time post } \\
\text { Immuni. } \\
\text { (WPV) }\end{array}$} & $\begin{array}{c}\text { S. dose* } \\
\text { Adj. vac***. }\end{array}$ & $\begin{array}{c}\text { S. dose } \\
\text { Non Adj. vac. }\end{array}$ & $\begin{array}{c}\text { D. dose** } \\
\text { Adj. vac. }\end{array}$ & $\begin{array}{c}\text { D. dose } \\
\text { Non-Adj. vac }\end{array}$ \\
\hline 2 & $16.2 \pm 0.650$ & $12.40 \pm 0.65$ & $14.5 \pm 0.550$ & $9.8 \pm 0.550$ \\
\hline 4 & $11.5 \pm 0.450$ & $10.45 \pm 0.45$ & $11.6 \pm 0.025$ & $9.8 \pm 0.150$ \\
\hline 6 & $11.3 \pm 0.195$ & $6.75 \pm 0.350$ & $11.2 \pm 0.210$ & $5.5 \pm 0.010$ \\
\hline 8 & $9.00 \pm 0.585$ & $6.70 \pm 0.075$ & $11.1 \pm 0.990$ & $4.2 \pm 0.035$ \\
\hline 10 & $6.20 \pm 0.575$ & $5.90 \pm 0.120$ & $8.30 \pm 0.990$ & $4.2 \pm 0.035$ \\
\hline 12 & $6.0 \pm 0.0007$ & $5.20 \pm 0.276$ & $4.10 \pm 0.042$ & $3.8 \pm 0.230$ \\
\hline
\end{tabular}

WPV: week post vaccination

* : 5 single dose regimen

** : double dose regimen

*** : Adj.- Vitamin E (vE) and Selenium (Se) 
Table 2. Comparative evaluation of immunofluorscent antibody titer in sera of experimentally immunized mice post receiving adjuvated and Non-adjuvanted Vero cell rabies virus vaccine

\begin{tabular}{|c|c|c|c|c|}
\hline \multirow{2}{*}{$\begin{array}{c}\text { Time post } \\
\text { Immuni.( WPV) }\end{array}$} & $\begin{array}{c}|c| \\
\text { S. dose* } \\
\text { Adj. vac.*** }\end{array}$ & $\begin{array}{c}\text { S. dose Non- } \\
\text { Adj. vac. }\end{array}$ & $\begin{array}{c}\text { D.dose } \\
\text { Adj. vac. }\end{array}$ & $\begin{array}{c}\text { D.dose** } \\
\text { Non-Adj. vac }\end{array}$ \\
\hline 2 & 64 & 32 & 32 & 32 \\
\hline 4 & 256 & 64 & 64 & 64 \\
\hline 6 & 256 & 128 & 256 & 64 \\
\hline 8 & 512 & 512 & 512 & 128 \\
\hline 10 & 1024 & 512 & 512 & 64 \\
\hline 12 & 1024 & 256 & 256 & 64 \\
\hline
\end{tabular}

WPV: week post vaccination

* : 5 single dose regimen

** : double dose regimen

***: Adj. - Vitamin E (vE) and Selenium (Se)

\section{Discussion}

There are growing researches about the roles of trace elements namely, zinc, copper, selenium, and others in immunity and the mechanisms that underlie such roles. $\alpha$-Tochopherol and selenium have interactive effects on lymphocytes response to antigens suggesting that micronutrient status is important when interpreting results of in vitro lymphocyte function (Panousis et al.,2001). vE-selenium either administered individually or combined have an effect on the immune response either cellular or humoral immunity (Fitzgerald and Rastogi, 1985; Hostnik and Grom,1997;. Finch and Turner, 1986). Immune potentiating activity of antioxidants is well known (Finch and Turner, 1986), where a higher antibody level against Newcastle Virus Vaccine (NCVV) was detected 10-21 day post immunization of chicks with vE-selenium adjuvated vaccine than that induced by non adjuvated vaccine. Also, body weight of chicks showed a noticed increase post receiving a diet containing $0.5 \mathrm{mg} / \mathrm{Kg}$ selenium and $300 \mathrm{IU} / \mathrm{ml}$ vitamin E. A significantly higher antibody titer, evaluated by hemagglutination inhibition test (HIT) and ELISA assays 10 days post immunization was attributed to $0.6 \mathrm{mg} / \mathrm{kg}$ selenium and $150 \mathrm{IU} / \mathrm{ml}$ vitamin E. Data in literature (Kodama, 1996 ; Panousis et al., 2001) reported that the optimum growth rate was concomitant with immune potentiating activity that may be achieved by combined supplementation of selenium and vitamin $\mathrm{E}$. The results obtained in the present work (Table 1 and 2) are in a good agreement with the results in literature (Kodama,1996 ; Panousis et al., 2001) where the antibody level post immunization of mice using the vE-selenium adjuvated rabies virus vaccine was higher than that induced post immunization with non adjuvated vaccine. Although Competitive Enzyme-Linked Immunosorbent Assay (cELISA) was developed as an reliable and highly correlative alternative, for the Mice Virus Neutralization Test (MVNT) (Arai et al., 2002) direct ELISA could be used to evaluate the neutralizing antibody developed in human sera post immunization using purified Vero cell rabies virus vaccine; (Vero-Rab) and the determined antibody levels were correlated to those evaluated using Mice Neutralization Assay 
(MNA) (El- Karamany, 1987 ,1988). The immune response to rabies virus vaccine, evaluated by ELISA, revealed that the antibody titer in sera of laboratory animals of different groups till the end of the test period (6 months) was higher than the protective level (> $0.5 \mathrm{IU} / \mathrm{ml})$. Also, the IFA revealed that the maximum IFA titer (1024) was detected on $10^{\text {th }}-12^{\text {th }}$ weeks post vaccination using 5 single dose regimen of adjuvated vaccine. In the mean time, antibody level detected post immunization of laboratory animals using 5 single dose of non adjuvated vaccine and double dose regimens of adjuvated vaccine recording a IF antibody titer of 512 which was maintained through $8^{\text {th }}-10^{\text {th }}$ week post immunization, whereas the double dose regimen of non adjuvated vaccine showed the least IF antibody titer of 128 detected on the $8^{\text {th }}$ week. Although, the antibody level detected by IFA was not completely correlated to the antibody levels assayed by Rapid Focus Fluorescent Inhibition Test (RFFIT), they could prevent the development of encephalitis post challenge of immunized mice using 100 MICLD $_{50}$ of CVS, 6 months post vaccination. On the contrary it was reported (Burgoyne et al., 1985 ; Sugiyama et al., 1997) that neither immune response to rabies vaccine nor lymphocyte blastogenic response to nonspecific mitogens was affected by selenium, and the most currently used adjuvant; alum (aluminum hydroxide gel), showed no effect on the immune response to rabies virus vaccine; the antibody level detected in sera of vaccinated hosts immunized with alum adjuvated vaccine was less than the antibody level developed post immunization with non-adjuvated rabies virus vaccine. In the same time, the intensive research work carried out in the last three decades (Ellis et al., 1997 ; Burgoyne et al., 1985) suggested the synergetic activity of aluminum hydroxide (alum) adjuvated rabies virus vaccine either it was used alone or adjuvated aviridine was clear and the two vaccines could provoke the immune response with titer persisted above $2.264 \log _{10} \mathrm{SN}_{50}(\mathrm{SN}=$ serum neutralization), throughout the study, and the mean antibody titer at 30 day post vaccination was numerically higher for the alum adjuvated vaccine ,but the antibody level developed post immunization with avridine containing vaccine was numerically higher on day 90 . Although, no significant elevation was reported following re-vaccination at day 90 the antibody level induced by the avridine containing vaccine was higher and persisted till the end of the study; the difference was significant $(\mathrm{P}<$ 0.05 ) on days 180, 360 and 390 (Burgoyne et al., 1985). Concerning different immunization regimens and related immune response, the present results revealed that the classical immunization regimen, 5; doses of vE-selenium adjuvated vaccine induced a long lasting and higher antibody level than that elicited post immunization using a modified regimen; double dose. Data recorded here (Table 1 and 2) are in agreement with those reported by (Umeharal et al., 2002 ; Madhusudana et al., 2001) those authors reported that, there was an excellent immune response with more than the protective titer $(>0.5 \mathrm{IU} / \mathrm{ml})$ up to the end of the observation period (3 years). More significantly, protective titers were detected in all subjects by day 7 and only minimal side reactions were observed. Also, it was concluded that this multi-site regimen with or without passive immunization had prevented the development of rabies encephalitis in these people bitten by confirmed rabid dogs. Also, the route of administration and dose number significantly influenced antibody level production and protection from challenge independently affected results, and that the extended challenge studies revealed that intramuscular vaccination of mice resulted in the highest anybody level and protection level equivalent to intraperitoneal $(\mathrm{I} / \mathrm{P})$ vaccination, and even multiple subcutaneous (S/C) vaccination resulted in a poor serum neutralizing antibody titer and far less protective than other routs. Further studies (Madhusudana et al., 2002) suggested that, it is possible to improve rabies vaccine potency evaluation in mice by 1 dose by intramuscular administration $(\mathrm{I} / \mathrm{M})$ and a delayed time of challenge. In the same way, a comparative evaluation of immune response to Fermi 
type vaccine and Vero cell rabies vaccine was monitored using mice model and human vaccinees revealing a protective antibody titer. Fermi type rabies virus vaccine produced in Ethiopia was evaluated in mice where immunized mice were challenged intra cranially with rabies virus at a concentration of 64 MICLD $_{50} 90$ days post initial vaccination and the level of neutralizing antibodies ranged from 4.6 to $25 \mathrm{IU} / \mathrm{ml}$. Boostering showed non significantly increased immune response. All immunized mice could withstand intracranial challenge and virus neutralizing antibodies in sera of human vaccinees immunized with prescribed Fermi vaccine were $>0.5 \mathrm{IU} / \mathrm{ml}$ detected by day 14 , but were non detectable by day 1 (Wunderli et al., 2003).

\section{Conclusion}

$\mathrm{vE}$ - Selenium as an immunostimulant could enhance the immune response of mice. Also, the single dose regimen of adjuvated vaccine is more preferable than the double dose regimen of immunization. The investigated vaccines both adjuvated and non-adjuvated were potentially immunogenic and could induce more than the protective anti-body titer post intramuscular immunization. Preclinical and clinical evaluation of $\mathrm{vE}$ selenium as an immunostimulant is recommended. Intraperitoneal immunization using Vero-Rab was not recommended where very low antibody levels were detected so intramuscular immunization route was preferred.

\section{Acknowledgement}

This work was supported by The Egyptian Organization for Biological Products and Vaccines (VACSERA Holding Company). Author would like to acknowledge Prof. Dr. Rifky El-Karamany, Ex-General Manager of R\&D Sector (VACSERA) for his comments on the present work and Mr. Ahmed Eid Fazary for preparing the manuscript.

\section{References}

1. Plotkin S.A. (1996). Vaccine Production in Human Diploid Cell Strains. Am. J. Epid., 94: 303 - 306.

2. Hayflick L. and Moorhead P.S. (1969). The serial cultivation of human diploid cell strains. Exp. Cell Res., 25:585-621.

3. Meslin F.X. and Kaplan M.M. (1996). General consideration in the production and use of brain tissue and purified chicken-embryo rabies vaccine for human use." Laboratory Techniques in Rabies" $4^{\text {th }}$ Ed. Geneva, World Health Organization: 221-233.

4. Wiktor T.J. (1969). Immunogencity of concentrated and purified rabies vaccine of tissue culture origin. Proc. Soc. Exp.Biol.Med. 131:799-805.

5. Wiktor T.J. (1973). Human cell culture rabies vaccine. JAMA, 224:1170-1171

6. Kissling R.E. (1985). Growth of rabies virus in non nervous tissue culture. Proc. Soc. Exp. Biol., 98: 223-227.

7. El- karamany R.M. (1987). Production in Vero Cells of an inactivated Rabies Vaccine from Strain FRV/K for Animal and Human use. Acta.Virol., 31: 321-328.

8. Boxer L.A. (1986). Regulation of phagocyte function of vitamin E adjuvant 407 Chicks.Poult.Sci.70:1709.

9. Preziosi P., Arnaud J., Manuguerra J.C. and Herchberg S. (1999). Impact of trace elements and vitamin supplementation on immunity and infections in institutionalized elderly patients: a randomized controlled trial. MIN. VIT. AOX. Geriatric network. Arch. Intern. Med., 12;159(7):748-51.

10. Kodama H. (1996). Essential trace elements and immunity Nippon Rinsho, 54(1):46-51.

11. Afzal M., Tengerdy R.P., Ellis R.P., Kimber-ling C.V. and Moms C.J. (1984). Protection of rams against epididymitis by a Brucella ovis-vitamin E adjuvant vaccine. Vet. Immunol. Immunopathol. 7:293-297

12. Franchini A., Canti M., Manfreda G., Bertuzzi S., Asdrubali G. and Franciosi C. (1991). Vitamin $\mathrm{E}$ as adjuvant in emulsified vaccine for chicks. Poult. Sci.,70(8):1709-15.

13. Tengerdy R.P. and Lacetera. N.G. (1991). Vitamin E adjuvant formulations in mice. Vaccine 9:204-208.

14. WHO (1996). Expert Committee on 
Biological Standardization Report, Geneva, World Health Organization (Laboratory Techniques in Rabies).

15. Hasse M., Seinsche D. and Seinsche W.(1985). The mouse neutralization test in comparison with rapid fluorescent focus inhibition test:Difference in the results in rabies antibody determination. Journal of Bilological standardization, 13:123-128.

16. Fitzgerald E.A., Rastogi S.C. (1985). A collaborative study to establish an international standard rabies immunoglobulin of human origin. Journal of biological standardization, 13:327-333.

17. Smith J.S, Yager P.A. and Bear G.M. (1973). A rapid reproducible test for determination of rabies neutralizing antibody.Bull.Wld.Hlth.Org.,48:535-541.

18. Hostnik P. and Grom J. (1997). An indirect immunofluorescent test for detection of rabies virus antibodies in foxes. J. wild Dis.,33(1):143-145.

19. Finch J.M., Turner R.J. (1986). Selenium supplementation in lambs: effects on antibody responses to a salmonella vaccine.Vet.Rec.,25;119(17):430-431.

20. Panousis N., Roubies N., Karatzias H., Frydas S., Papasteriadis A..(2001). Effect of selenium and vitamin $\mathrm{E}$ on antibody production by dairy cows vaccinated against Escherichia coli.Vet. Rec., 149(21):643-6.

21. Arai Y.T., Kimura M., Sakaue Y., Hamada A., Yamada K., Nakayama M., Takasaki T. and Kurani I. (2002). Antibody responses induced by immunization with a Japanese rabies vaccine determined by neutralization test and enzyme linked immunosorbent assay .Vaccine, 7;20(19-20): 2448-2453.

22. Sugiyama M., Yoshiki R., Tatsuno Y., Hiraga S., Itoh O., Gamoh K. and Minamoto N.(1997). A new competitive enzyme-linked immunosorbent assay demonstrate adequate immune levels to rabies virus in compulsorily vaccinated Japanese domestic dogs. Clin. Diag. Lab. immunol., 4(6):727-730.

23. Ellis R.G., Herdt T.H. and Stowe $H$ D.(1997). Physical, hematologic, biochemical and immunologic effects of supranutritional supplementation with dietary selenium in Holstein cows. Am. J. Vet. Res., 58(7):760-764.

24. Berlin B.S., Mitchell J.R., Burgoyne G.H., Brown W.E. and Goswick C. (1983). Rhesus diploid rabies vaccine (adsorbed), a new rabies vaccine: II. Results of clinical studies simulating prophylactic therapy for rabies exposure. JAMA; 249:2663-2665.

25. Burgoyne G.H., Kajiya K.D., Brown D.W., Mitchell J.R. ( 1985). Rhesus diploid rabies vaccine (adsorbed): a new rabies vaccine using FRhL-2 cells. J Infect Dis;152:204-210.

26. Umehara1 D., De-Lucca Neto I., Moro1 E., Bernard F.H. and Ito1 C.A. Rodrigues (2002). Rabies virus antibodies profile in cattle vaccinated with inactivated vaccine adjuvanted either with aluminum hydroxide alone or combined with aviridine .Arq. Inst. Biol. San Paulo, 69(1):23-28.

27. Zhonghua Shi Yan He Lin Chuang Bing (1999) Influence of aluminum adjuvant to experimental rabies vaccine. Du.Xue Za. Zhi. , 13(2):133-135.

28. Madhusudana S.N., Anand N.P and Shamsundar R. (2001). Evaluation of two intradermal vaccination regimens using purified chick embryo cell vaccine for post exposure prophylaxis of rabies.Natl. Med. J.India; 14(3):145-147.

29. Madhusudana S.N., Anand N.P and Shamsundar R. (2002). Economical multi-site intradermal regimen with purified chick embryo cell vaccine (Rabipur) prevents rabies in people bitten by confirmed rabid animals. Int. J. Infect. Dis., 6 (3):210-214.

30. Wunderli P.S., Dreesen D.W., Miller T.J. and Baer G.M. (2003) Effects of vaccine route and dosage on protection from rabies after intracerebral challenge in mice. Am. J. Vet. Res., 64(4):491-498.

31. Ayele W., Fekadu M., Zewdie B., Beyene M., Bogale Y., Mocha K. and Egziabher F.G. ( 2001). Immunogenicity and efficacy of Fermi-type nerve tissue rabies vaccine in mice and in humans undergoing post-exposure prophylaxis for rabies in Ethiopia. Ethiop Med. J.; 39(4):313-321.

32. Karamany R.M., Kazar J., Malik S.A., AL-mufti S. and Badria M (1988). Rapid quantitative assay of rabies postvaccination antibody by EIISA .APMIS SUPPL. 3 : 40-43.

33. Atanasiu P. (1973).Quantitative assay and potency test of antirabies serum and immunoglobulin. In:Kaplan M M. \& Koprowski H (EDs.). Laboratory Techniques in rabies, IIIrd edition, WHO Monogr.Ser.23,Geneva 1973,pp.314-318 
مناهضة المواد المضادة للأكسدة للإستجابة المناعية للفئران البيضاء من سلالة

(إن ـ أى ـ إتش) للقاح الكلب المنتج في خلايا الفيرو( فيرو. راب)

علي فهمي محمد السيا

الهيئة المصرية للمستحضر ات الحيوية و اللقاحات (فاكسير ا)

أظهرت نتائج تحصين للفئر ان البيضاء من سلالة (إن.أى.أتش) المحصنة بلقاح

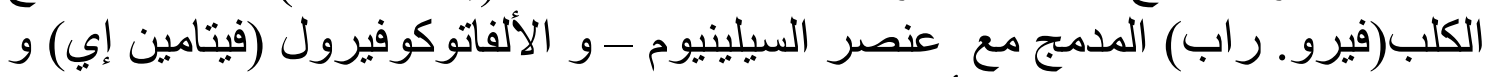

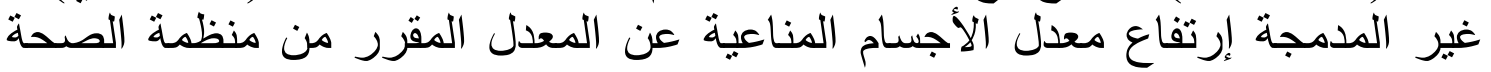

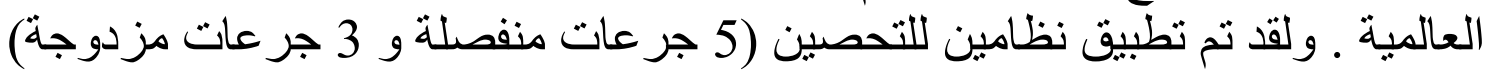

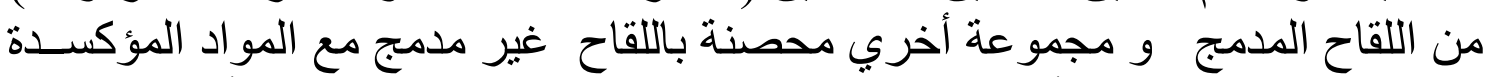

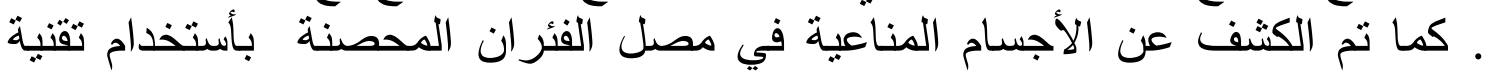

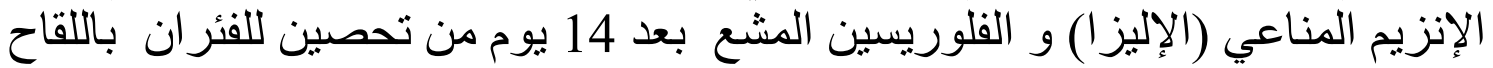

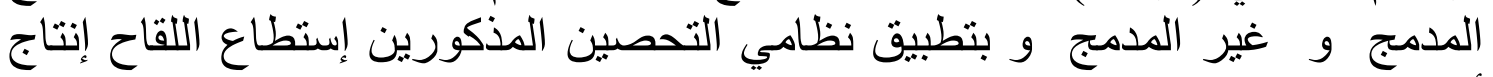

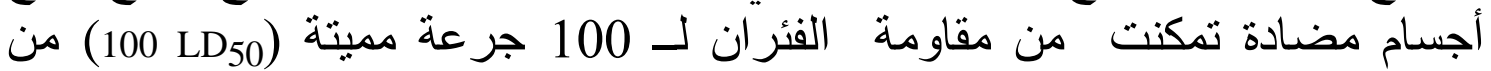

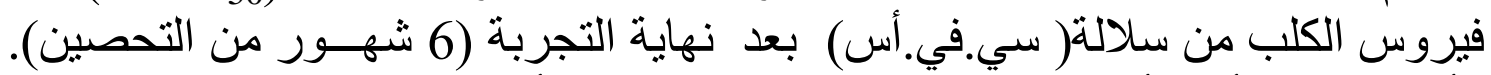

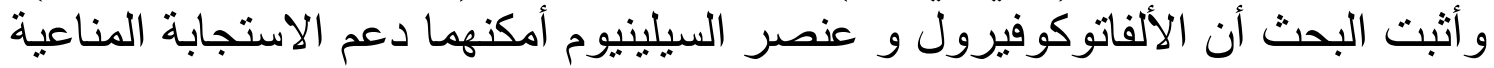

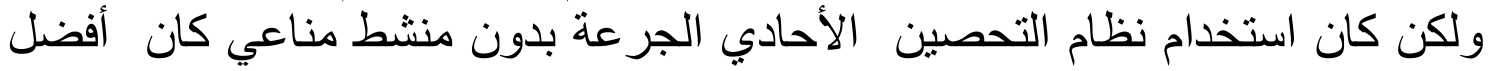
من نظام التحصين المزدوج الجنام التحبن. 